\title{
EVALUATION OF ANTIMICROBIAL ACTIVITY İN EXTRACTS OF DIFFERENT PARTS OF THREE TAGETES SPECIES
}

\author{
Elnaz LATIFIAN ${ }^{1 *}$, Cigdem OTUR ${ }^{2}$, Busra ABANOZ-SECGIN², Sahane Funda ARSLANOGLU1, \\ Aslihan KURT-KIZILDOGAN ${ }^{2}$ \\ ${ }^{1}$ Ondokuz Mayls University, Faculty of Agriculture, Department of Field Crops, Samsun, TURKEY \\ ${ }^{2}$ Ondokuz Mayls University, Faculty of Agriculture, Department of Agricultural Biotechnology, Samsun, \\ TURKEY \\ Corresponding author: eli.latifian@gmail.com
}

Received: 24.12.2019

\begin{abstract}
Indiscriminate use of antibiotics often results in the development of resistant microbial strains. The unprecedented increase in cases of antimicrobial drug resistance, the discovery of newer agents, particularly from natural plant metabolites, are required for the control of such prevalent and recurring infectious diseases worldwide. This study aimed to evaluate antibacterial and antifungal activities of extracts from different parts of Tagetes patula, Tagetes erecta, and Tagetes minuta, which are important medicinal plants. Five grams of airdried flower, leaf, and bud (only for $T$. patula and $T$. erecta) samples were extracted three times with methanol: water (4:1) at room temperature in the dark for $24 \mathrm{~h}$. The methanol: water extracts were combined, filtered, and concentrated to dryness using a rotary evaporator at $40{ }^{\circ} \mathrm{C}$. The extracts were screened for their in vitro antimicrobial activities against nine indicator strains [three Gram-positive bacteria (Staphylococcus aureus, Bacillus subtilis, and Enterococcus faecalis), three Gram-negative bacteria (Escherichia coli, Klebsiella pneumoniae, and Pseudomonas aeruginosa) and three fungi (Candida albicans, Aspergillus niger, and Phytophthora erythroseptica)] by Agar well diffusion assay. Broth microdilution method was used to determine minimum inhibition concentrations (MIC) of the extracts that showed antimicrobial activity against Grampositive bacteria and $P$. erythroseptica. The $T$. patula leaf extracts led to the highest antibacterial activity against $B$. subtilis ATCC 6633 with an inhibition zone of $17 \mathrm{~mm}$ and a MIC value of $256 \mu \mathrm{g} / \mathrm{ml}$. The bud and flower extracts of $T$. patula were potent against the same strain at an intermediary level. Also, the $T$. erecta bud extracts inhibited the growth of $E$. faecalis ATCC 29212 at a moderate level. In this study, only the $T$. patula flower extracts showed antifungal activity against $P$. erythroseptica strain with a MIC value of $426.7 \mu \mathrm{g} / \mathrm{ml}$. Our findings make an excellent contribution to revealing the antimicrobial activity of $T$. erecta, $T$. patula and $T$. minuta by comparing the methanol-extracted leaf, bud, and flower parts at a single experimental setup.
\end{abstract}

Keywords: Antimicrobial activity, Extraction, Tagetes patula, Tagetes erecta, Tagetes minuta

\section{INTRODUCTION}

Tagetes sp. contains about 56 species belonging to the Asteraceae family, many of which have different chemical and biochemical properties, and can produce high pharmaceutical and nutritional value compounds. Extracts of Tagetes sp. has vast amount of orange-yellow carotenoids (Ibrahim et al., 2018). Tagetes minuta L., known as marigold, is a single or perennial plant and can spread from tropical to temperate climate under wide climatic conditions. T. minuta extracts are ingredients of medicinal drogs used to treat common cold, inflammation, bowel and stomach illnesses, skin infections, cough, cold and, wound (Ali et al., 2014).

In addition, Obongoyai et al. (2010) reported inhibition of the Fusarium oxysporum conidium, a soilborne pathogen, by T. minuta. Antimicrobial studies with this species were reviewed in detail (dos Santos et al., 2017). In particular, the literature mainly focused on antimicrobial activities of essential oil extracts. T. minuta has a high larvicidal effect and is used as a housefly repellent in Kenya. Tagetes patula, also known as France marigold, is a one-year plant with a wide distribution. It synthesizes similar ingredients like $T$. minuta but also has patuletin and patulitrin, rare antimicrobial and antiinflammatory chemicals. It was reported that this species synthesizes different chemicals like benzofuran, flavonoid and carotenoid. The effects of different organic fractions, different plant parts, and their several combinations in $T$. patula were investigated in different studies (Politi et al., 2016). Tagetes erecta is another type of marigold with high pigment content, and several studies evaluated metabolite production, phytoremediation potential, and stress tolerance strength. Like the other two species, it 
contains the active substance used in the treatment of diseases such as ulcers, eye diseases, rheumatism, and bronchitis. The flower extract contains lutein, which can be used as a nutrient and food dye (Feng et al., 2018).

Nowadays, scientific studies have returned to 'Natural', products (Santos et al., 2017). Researches have focused intensively on finding pharmaceutical equivalents of traditional uses of medicinal plants, as well as research on the discovery of new antimicrobial compounds from a wide variety of plants (Chandra et al., 2017; Chootip et al., 2017). In this context, the discovery of natural plant metabolites as well as the production of high amounts of existing ones is of great industrial importance. However, increasing multidrug resistance in pathogenic microorganisms necessitates screening new antibiotic sources. In contrast to synthetic drugs, plant-derived antimicrobials have no side effects and they have known potential in treatment of infectious disease (Doughari and Manzara, 2008). So far, many plant species have been tested for their antimicrobial properties, but the vast majority have not been adequately evaluated. Studies in the literature of Tagetes sp. belong only to a certain organ or a single period of development and even to examples taken from herbalists. Therefore, this study makes a good contribution to the related literature by comparatively evaluating antimicrobial activities of the samples extracted from leaf, bud and flower parts of three different Tagetes species.

\section{MATERIALS AND METHODS}

\section{Plant material}

Three species (T. erecta, $T$. minuta and $T$. patula) were planted on 30 April-1 May, 2019 in the Field Crops Experiment Area of Faculty of Agriculture, Ondokuz Mayis University. The leaves, buds, and flowers from $T$. erecta and T. patula were collected on 31 May, 2019. For $T$. minuta, the leaves and buds were collected on 2 October, 2019 while the flower parts were harvested on 14 October, 2019. All the materials collected, were dried in an oven at $35^{\circ} \mathrm{C}$ for $48 \mathrm{~h}$.

\section{Extraction}

An extraction procedure reported in Hamza et al. (2006) was used with slight modifications Firstly, $5 \mathrm{~g}$ of the dried plant materials were extracted by maceration within $75 \mathrm{ml}$ of a $4: 1$ ratio of methanol: water mixture under the dark conditions and at room temperature for 24 h (Hamza et al., 2006). This step was repeated three times during $72 \mathrm{~h}$. The extracts from each step were collected, filtered, and concentrated at $40{ }^{\circ} \mathrm{C}$ using a rotary evaporator to give a final dry weight of $300 \mathrm{mg}$. The extracts were stored at $-86{ }^{\circ} \mathrm{C}$ and resuspended with $1 \mathrm{ml}$ of $80 \%$ methanol before antimicrobial testing.

\section{Antimicrobial activity}

\section{Indicator microorganisms:}

Indicator strains used in this study are Bacillus subtilis ATCC6633, Enterococcus faecalis ATCC 29212, Staphylococcus aureus ATCC 25923, Escherichia coli
ATCC 25922, Klebsiella pneumoniae ATCC 700603, Pseudomonas aeruginosa ATCC 27853, Candida albicans ATCC 10231, Aspergillus niger ATCC 16404 and Phytophthora erythroseptica. All microorganisms except for $P$. erythroseptica were purchased from Refik Saydam National Type Culture Collection (Ankara, Turkey). P. erythroseptica was kindly provided from Dr. Sezer Okay (Hacettepe University, Ankara, Turkey).

\section{Agar well diffusion method:}

The extracts were tested against indicator strains using the Agar well diffusion method described in Romero et al. (1984). The results were interpreted according to Clinical and Laboratory Standards Institute (CLSI) recommendations (CLSI M100-S24, CLSI M44-A2, CLSI M51-A). Amikacin $(30 \mu \mathrm{g})$ and ketoconazole $(300 \mu \mathrm{g})$ were used as standards for bacteria and fungi, respectively. Indicator strains were grown in Mueller Hinton Broth (MHB, for bacteria) and Sabouraud Dextrose Broth (SDB, for fungi) up to an $\mathrm{OD}_{600}$ value of 1.0. Then, $3.3 \mathrm{ml}$ of the cultures were mixed gently with $100 \mathrm{ml}$ of molten (at $45{ }^{\circ} \mathrm{C}$ ) MHA/SDA. Mediamicroorganism mixtures were poured into Petri dishes and allowed to solidify. A $50 \mu \mathrm{l}$ of extracts were added to the wells generated in the solid media by using a cup borer ( 6 $\mathrm{mm})$. All Petri dishes were kept at $+4{ }^{\circ} \mathrm{C}$ for $2 \mathrm{~h}$. Then, bacterial cultures were incubated at $37^{\circ} \mathrm{C}$ for $12-15 \mathrm{~h}$; fungal cultures were incubated at $26^{\circ} \mathrm{C}$ for $24 \mathrm{~h}$. Inhibition zones that occurred around the wells were measured as diameter $(\mathrm{mm})$. The experiment was repeated two times, and two technical replicates were used. Methanol control was also included to the experiments.

\section{Broth microdilution method:}

The extracts that show remarkable inhibition zones against indicator strains by agar well diffusion assay were further analyzed quantitatively to determine Minimum Inhibitory Concentration (MIC) values. MIC; refers to the minimum concentration of substance required to inhibit microbial growth. The results were evaluated according to CLSI recommendations (CLSI M07-A10 for bacteria, CLSI M27-A3 and CLSI M27-S4 for yeast, CLSI M38A2 for filamentous fungi). Firstly, $100 \mu \mathrm{l}$ of Cation adjusted Mueller-Hinton Broth (CA-MHB) (Oxoid) were added to the 96-well round-bottomed microtiter plates. Double dilution series of extracts/ standard antibiotics (Amikacin for bacteria, ketoconazole for fungi) were added into the wells in a concentration scale ranging from 512 to $0.125 \mu \mathrm{g} / \mathrm{ml}$. Microbial cultures were diluted to 0.5 McFarland solution $\left(\cong 1-4 \times 10^{8} \mathrm{CFU} / \mathrm{ml}\right)$ at $\mathrm{OD}_{625}$. A hundred $\mu \mathrm{l}$ of the ten-fold diluted microbial cultures were added to each well. The microdilution plates were first kept at $4{ }^{\circ} \mathrm{C}$ for $2 \mathrm{~h}$ and incubated at $37^{\circ} \mathrm{C}$ for $12-15 \mathrm{~h}$ for bacteria. For fungal strains, the incubation temperature and time were $26^{\circ} \mathrm{C}$ and $24-48 \mathrm{~h}$. The MIC values were evaluated by turbidity observation in the wells. The experiments were performed as three technical replicates. The control reactions were also included (medium and extract without inoculum, medium and inoculum without 
extract, medium and inoculum with methanol instead of extract).

\section{RESULTS AND DISCUSSION}

Following maceration, the extracts were collected, filtered with blotting paper, and then kept in $-86{ }^{\circ} \mathrm{C}$ (Figure 1).

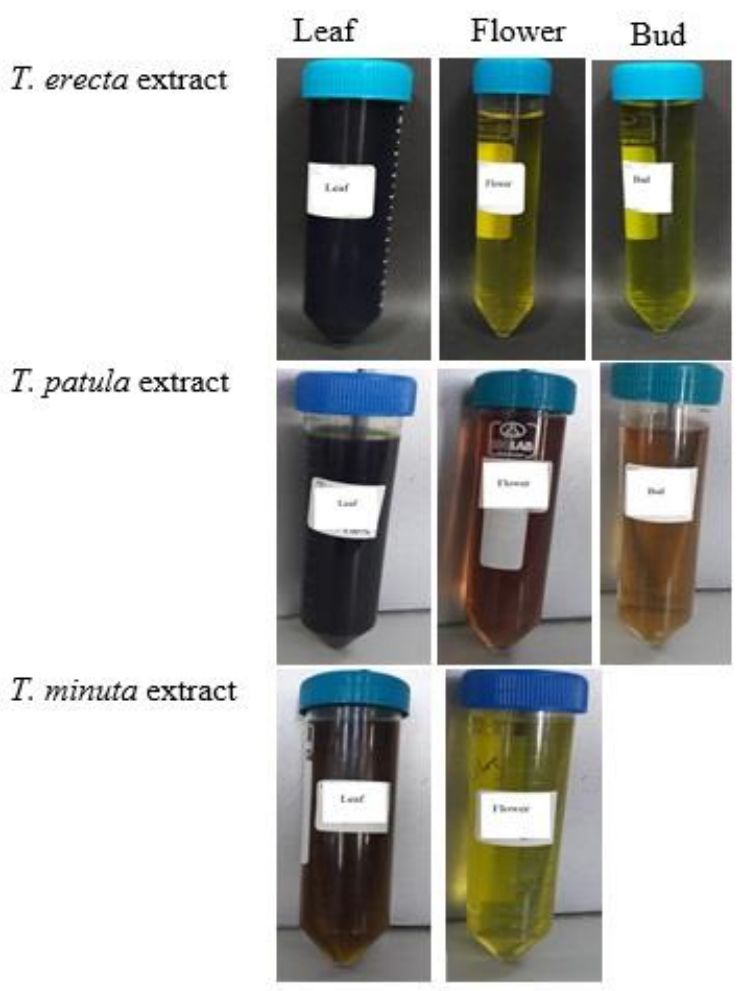

Then, $1.8 \mathrm{ml}$ of extracts were transferred to $2 \mathrm{ml}$ Eppendorf tubes and were flown in evaporator at $40^{\circ} \mathrm{C}$ for 9 h. $300 \mathrm{mg} / \mathrm{ml}$ extracts were dissolved with $1 \mathrm{ml}$ of $80 \%$ methanol. By using six different pathogenic bacteria, two fungi and a yeast as indicator organisms, antimicrobial and antifungal activity of the extracts were determined by Agar well diffusion method (Table 1).

Bioassay results showed that the $T$. erecta leaf and bud extracts, the $T$. patula leaf, flower and bud extracts, and the leaf and flower extracts of $T$. minuta contain phytoconstituents that have antimicrobial activity against Gram-positive bacteria. The extracts obtained from $T$. erecta buds showed antibacterial activity against $E$. faecalis ATCC 29212 at an intermediary level. In particular, the antimicrobial activity results of $T$. patula extracts were found more prominent. All extracts obtained from different parts of $T$. patula resulted in inhibition zone formation against $B$. subtilis ATCC 6633, S. aureus ATCC 25923 and E. faecalis ATCC 29212, all Grampositive bacteria tested. Indeed, the leaf and bud extracts of $T$. patula provided the highest antimicrobial activity in this study and led to inhibition of B. subtilis ATCC 6633 at a high level (inhibition zone with $17 \mathrm{~mm}$ ). B. subtilis ATCC 6633 was also susceptible to $T$. patula flower and bud extracts at an intermediary level (15-15.5 mm). Only, the extracts obtained from $T$. patula flowers showed antifungal acitivity against $P$. erythroseptica among the tested fungi by causing the same inhibitory effect as that of ketoconazole $(10.5 \mathrm{~mm})$. None of the extracts showed antibacterial activity on the Gram-negative microorganisms tested.

Figure 1. The methanol extracts obtained following maceration of different parts of Tagetes species.

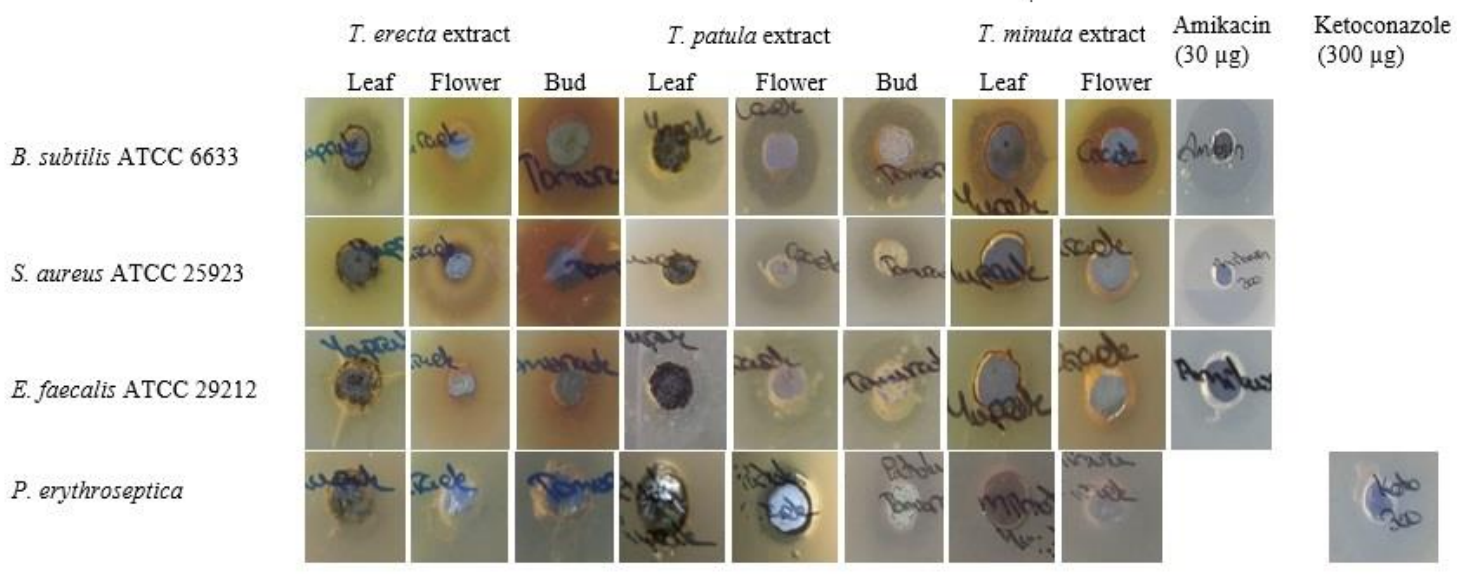

Figure 2. Inhibition zones obtained from flower, bud, and leaf extracts from T. erecta, T. minuta and T. patula against indicator strains. 
Followingly, MIC values of the extracts having remarkable antimicrobial activity as shown by bioassay, were determined by the broth microdilution method (Table 2). The highest MIC value was recorded as 256 $\mu \mathrm{g} / \mathrm{ml}$ and obtained against B. subtilis ATCC 6633 with the use of the $T$. erecta bud extracts and the leaf extracts of both $T$. patula and $T$. minuta. In addition, the $T$. erecta leaf extracts and the $T$. patula flower extracts resulted in a MIC value of $341.3 \mu \mathrm{g} / \mathrm{ml}$ against B. subtilis ATCC 6633 The higher MIC value of $426.7 \mu \mathrm{g} / \mathrm{ml}$ was obtained against $S$. aureus ATCC 25923 when the $T$. patula leaf extracts were used. In this study, the only $T$. patula flower extracts exerted antifungal activity against $P$. erythroseptica with a MIC value of $426.7 \mu \mathrm{g} / \mathrm{ml}$. The remaining MIC results were recorded as $512 \mu \mathrm{g} / \mathrm{ml}$ or more (indicated as Not determined) against other methanol extracts tested in the broth microdilution method.

Our results indicate a broad spectrum of antimicrobial activity for $80 \%$ methanol extracts of different organ parts belonging to $T$. erecta, $T$ patula and $T$. minuta, and accorded well with the previous reports. For instance, Verma and Verma (2012) investigated the antimicrobial activity of five different parts (flower, root, leaves, bud, stem) of T. erecta exracted with ethanol (by using soxhlet apparatus) against five Gram-positive strains by Agar disc diffusion assay. The ethanols extracts exerted different levels of antibacterial activity. Thereby, their bioassay results showed that both leaf and flower extracts provided remarkable sensitivity by Staphlococcus lutea and Bacillus circulence. In another study, Ali et al. (2019) obtained chloroform extract of $T$. erecta flowers and tested its antibacterial activity against nine bacteria using Agar disc diffusion and Agar well diffusion methods. They found that the Agar well diffusion method provided better antibacterial activity results compared to the Agar disc diffusion method. In addition, they showed that Salmonela spp. was the most sensitive indicator strain providing $15 \mathrm{~mm}$ inhibition zone when exposed to 62.5 $\mathrm{mg} / \mathrm{ml}$ of the $T$. erecta flower extract. Padalia and Chanda (2015) evaluated antimicrobial efficacy of different solvent extracts of $T$. erecta flower, both alone and in combination with antibiotics. They obtained maximum inhibition against indicator strains when polar organic solvents especially acetone and methanol were used in the extraction process by cold percolation method. The combination of the flower extract and the antibiotics provided a synergistict effect against human pathogens.

As shown in Table 1 and 2, our T. patula extracts exerted more efficient antimicrobial activity against the indicator strains. In the literature, there are different approaches indicating antimicrobial potebtial of $T$. patula extracts. For example, Ayub et al. (2017) evaluated antimicrobial properties of $T$. patula ant $T$. erecta petals extracted with methanol and $\mathrm{n}$-hexane, respectively, through the Agar disc diffusion method and MIC determination. The $T$. patula petal extracts showed better antibacterial activity than that of $T$. erecta by leading to larger inhibition zones (12.4 -20.2 $\mathrm{mm}$ ) and smaller MIC values $(0.19-4.05 \mathrm{mg} / \mathrm{ml})$. In addition, Jain et al. (2012) investigated in vitro antibacterial potential of methanol extracts of $T$. erecta and $T$. patula flowers against different pathogens by using the Agar disc diffusion method and test tube dilution method. Their methanol extracts of $T$. erecta and $T$. patula flowers provided MIC values ranging from 20 to $160 \mathrm{mg} / \mathrm{ml}$ for most of the tested bacteria. It was previously reported that the use of methanol as organic solvent was found to be effective for extraction of phenolic compounds (Hussain et al., 2011). Antifungal activity of methanol-treated $T$. patula thiophene extracts were tested against two phytopathogenic fungi, Botrytis cinerea and Fusarium moniliformin, in an earlier study by Mares et al. (2002). Accordingly, they observed growth of fungal strains in SDA including different concentrations of extracts (5-10$50 \mu \mathrm{g} / \mathrm{ml})$. The results showed that $B$. cinerea had a high dose-dependent inhibition with a remarkable difference upon to light regimen. Later, Faizi et al. (2008) performed a bioassay-guided isolation study performing antimicrobial activity experiments on different parts of $T$. patula, especially on flowers at the same time. In another study, ethanol extracts of $T$. patula flowers and aerial parts were assayed on Microsporum canis and Trichophyton rubrum to indicate it potential acaricide activity. Therefore, they found strong inhibition of both strain by the flower extracts (MIC: $193.3 \mu \mathrm{g} / \mathrm{ml}$ and $253.9 \mu \mathrm{g} / \mathrm{ml}$, respectively, for $M$. canis and $T$. rubrum) and by the arerial parts against $T$. rubrum $(312.5 \mu \mathrm{g} / \mathrm{ml})$. Recently, Faraz et al. (2020) have reported pharmacognostic, antimicrobial and toxicological activities of T. patula L. In that study, ethanol extracted $T$. patula flowers provided good antimicrobial and larvacidal activities against human pathogens and brine shrimps, respectively. 
Table 1. Evaluation of antimicrobial activity of different Tagetes extracts by Agar well diffusion method

\begin{tabular}{|c|c|c|c|c|c|c|c|c|c|c|c|}
\hline \multicolumn{12}{|c|}{ Zone diameter (mm) } \\
\hline & \multirow{2}{*}{\multicolumn{3}{|c|}{$\begin{array}{c}\text { T. erecta extract (15 } \\
\mathrm{mg})\end{array}$}} & \multirow{2}{*}{\multicolumn{3}{|c|}{ T. patula extract (15 mg) }} & \multirow{2}{*}{\multicolumn{2}{|c|}{$\begin{array}{l}\text { T. minuta extract } \\
(15 \mathrm{mg})\end{array}$}} & \multirow{2}{*}{$\begin{array}{c}\text { Amikacin } \\
(30 \mu g)\end{array}$} & \multirow{3}{*}{$\begin{array}{l}\text { Ketoconazole } \\
\quad(300 \mu \mathrm{g})\end{array}$} & \multirow[t]{3}{*}{$\begin{array}{c}\text { CLSI } \\
(\mathbf{S} / \mathbf{I} / \mathbf{R}) * *\end{array}$} \\
\hline & & & & & & & & & & & \\
\hline & Leaf & Flower & Bud & Leaf & Flower & Bud & Leaf & Flower & & & \\
\hline $\begin{array}{ll}\text { B. subtilis ATCC } \\
6633\end{array}$ & 11 & $\mathrm{ND}^{*}$ & 11 & $\begin{array}{c}17 \pm 2.1 \\
(\mathbf{S})\end{array}$ & $15(\mathbf{I})$ & $\begin{array}{l}15.5 \pm 0.7 \\
\text { (I) }\end{array}$ & $11.5 \pm 0.7$ & 13 & $29.5 \pm 2.1$ & ND & $\geq 16 / 15-16 \leq 15$ \\
\hline $\begin{array}{l}\text { S. aureus ATCC } \\
25923\end{array}$ & ND & ND & 12 & 10 & 12 & 10 & ND & ND & $26.5 \pm 2.1$ & ND & $\geq 17 / 15-16 \leq 14$ \\
\hline $\begin{array}{l}\text { E. faecalis ATCC } \\
29212\end{array}$ & ND & ND & $\begin{array}{l}13 \\
\text { (I) }\end{array}$ & 10 & $11.5 \pm 0.7$ & 12 & ND & ND & 256 & ND & $\geq 16 / 13-15 \leq 12$ \\
\hline P. erythroseptica & ND & ND & ND & ND & \begin{tabular}{|l|}
$10.5 \pm 0.7$ \\
\end{tabular} & ND & $\mathrm{ND}$ & $\mathrm{ND}$ & ND & $10.5 \pm 0.7$ & ND \\
\hline
\end{tabular}

*ND: Not Determined**S/I/R: S, refers to sensitivity of the strains against the extract; I, refers to the susceptibility of the strains against the extract at an intermediary level; $\mathrm{R}$, refers to resistance of indicator strains against the extract.

Table 2. MIC $(\mu \mathrm{g} / \mathrm{ml})$ values of the Tagetes species extracts against indicator strains

\begin{tabular}{|c|c|c|c|c|c|c|c|c|c|c|}
\hline \multicolumn{10}{|c|}{ MIC $(\mu \mathrm{g} / \mathrm{ml})$} & \multirow{3}{*}{\begin{tabular}{|l} 
CLSI for \\
MICs \\
(S/I/R)**
\end{tabular}} \\
\hline & \multicolumn{2}{|c|}{ T. erecta extract } & \multicolumn{3}{|c|}{ T. patula extract } & \multicolumn{2}{|c|}{ T. minuta extract } & \multirow[t]{2}{*}{ Amikacin } & \multirow[t]{2}{*}{ Ketoconazol } & \\
\hline & Leaf & Bud & Leaf & Flower & Bud & Leaf & Flower & & & \\
\hline B. subtilis ATCC 6633 & $341.3 \pm 147.8$ & 256 & 256 & $341.3 \pm 147.8$ & 512 & 256 & $426.7 \pm 147.8$ & $1.5 \pm 0.7$ & ND* & $\leq 16 / 32 / \geq 64$ \\
\hline S. aureus ATCC 25923 & ND & 512 & $426.7 \pm 147.8$ & 512 & 512 & ND & ND & $5 \pm 2.7$ & ND & $\leq 16 / 32 / \geq 64$ \\
\hline $\begin{array}{l}\text { E. faecalis ATCC } \\
29212\end{array}$ & ND & 512 & 512 & 512 & 512 & ND & ND & 256 & ND & $\leq 64 / 128 / \geq 256$ \\
\hline P. erythroseptica & ND & ND & ND & $426.7 \pm 147.8$ & ND & ND & ND & ND & 256 & ND \\
\hline
\end{tabular}

*ND: Not determined

$* * \mathrm{~S} / \mathrm{I} / \mathrm{R}: \mathrm{S}$, refers to sensitivity of the strains against the extract; I, refers to the susceptibility of the strains against the extract at an intermediary level; $\mathrm{R}$, refers to resistance of indicator strains against the extract.

Regarding to T. minuta, our results included the leaf and flower extracts as we haven't harvested the buds, because of the small size and low extract yield. Unlike $T$. erecta and $T$. patula extracts, the antimicrobial activity was only recorded against $B$. subtilis ATCC 6633 strain resulting in inhibition zones of 11-13 $\mathrm{mm}$ and MIC values of 256 and $426.7 \mu \mathrm{g} / \mathrm{ml}$, respectively, for the leaf and flower extracts. In the literature, Ali et al. (2014) investigated essential oil composition of $T$. minuta leaves and evaluated its antimicrobial activities by the Agar disc diffusion assay. They showed that the essential oil exerted remarkable antimicrobial activity against methicillinresistant Staphylococcus aureus (MRSA) and C. albicans with the inhibition zones of 23 and $26 \mathrm{~mm}$, respectively. Gakuubi et al. (2016) characterized essential oils of $T$. minuta and determined the antibacterial activity of essential oils against three phytopathogenic bacteria, namely, Pseudomonas savastanoi pv. phaseolicola, Xanthomonas axonopodis pv. phaseoli, and Xanthomonas axonopodis pv. manihotisdos. Among them, P. savastanoi pv. phaseolicola was the most sensitive strain by exhibiting 41.8-44.8 mm inhibition zones. The MIC values against the tested bacteria were recorded as 95-190 $\mathrm{mg} / \mathrm{ml}$ at $48 \mathrm{~h}$. Later, dos Santos et al. (2017) critically reviewed the related studies on antimicrobial activity of $T$. minuta. They indicated that the methanol was the most frequently used organic solvent in the extraction process and this organic solvent leads to extraction of some metabolites such as polyphenols, glycosides and flavonoids (Rauha et al., 2000).

In conclusion, we obtained a broad range of antibacterial activity against human pathogen Grampositive bacteria by using methanol extracts of three different Tagetes species. In particular, the all T. patula extracts exhibited remarkable antibacterial activity, while a mild level of antifungal activity was recorded against $P$. erythroseptica, a phytopathogenic fungus with the use of only the flower extracts. Among the tested strains the most susceptible one was B. subtilis ATCC 6633. Overall, our results are comparable with the literature data as the comparison of antimicrobial efficacy of three different organ parts from the three Tagetes sp., make a good contribution in this area. Our future studies will be focused on characterization of chemical composition of our extracts especially, the ones that showed the antimicrobial activity in the current study.

\section{LITERATURE CITED}

Ali, N.A.A., F.S. Sharopov, A.G. Al-Kaf, G.M. Hill, N. Arnold, S.S. Al-Sokari, W.N. Setzer and L. Wessjohann. 2014. Composition of essential oil from Tagetes minuta and its cytotoxic, antioxidant and antimicrobial activities. Natural Product Communications. 9:1934578X1400900233.

Ali, Z.A., T.M. Jasim and W.M. Alani. 2019. Antibacterial activity of chloroform extract from Tagetes Erecta $L$. flowers. Al-Mustansiriyah Journal of Pharmaceutical Sciences 19: 7-15.

Ayub, M.A., A.I. Hussain, M.A. Hanif, S.A.S. Chatha, G.M. Kamal, M. Shahid and O. Janneh. 2017. Variation in phenolic profile, $\beta$-Carotene and flavonoid contents, biological activities of two Tagetes species from Pakistani flora. Chemistry and Biodiversity. 14:e1600463.

Chandra, H., P. Bishnoi, A. Yadav, B. Patni, A.P. Mishra and A.R. Nautiyal. 2017. Antimicrobial resistance and the alternative resources with special emphasis on plant-based antimicrobials - a review. Plants. 6(2): 6-16.

Chootip, K., N. Chaiyakunapruk, N. Soonthornchareonnon, C.N. Scholfield and A. Fuangchan. 2017. Efficacy and safety of 
"Yahom" as a traditional Thai herbal therapy: a systematic review. Journal of Ethnopharmacology 196: 110-123.

CLSI M27-A3 (Clinical and Laboratory Standards Institute). 2008. Reference method for broth dilution antifungal susceptibility testing of yeast. Clinical and Laboratory Standards Institute, Wayne.

CLSI M38-A2 (Clinical and Laboratory Standards Institute). 2008. Reference method for broth dilution antifungal susceptibility testing of filamentous fungi. Clinical and Laboratory Standards Institute, Wayne.

CLSI M44-A2 (Clinical and Laboratory Standards Institute). 2009. Method for antifungal disk diffusion susceptibility testing of yeasts. Clinical and Laboratory Standards Institute, Wayne.

CLSI M51-A (Clinical and Laboratory Standards Institute). 2010. Method for antifungal disk diffusion susceptibility testing of non dermatophyte filamentous fungi. Clinical and Laboratory Standards Institute Wayne.

CLSI M27-S4 (Clinical and Laboratory Standards Institute). 2012. Reference method for broth dilution antifungal susceptibility testing of yeasts. Clinical and Laboratory Standards Institute, Wayne.

CLSI M100-S24 (Clinical and Laboratory Standards Institute). 2014. Performance standards for antimicrobial susceptibility testing. Clinical and Laboratory Standards Institute, Wayne.

CLSI M07-A10 (Clinical and Laboratory Standards Institute). 2015. Methods for dilution antimicrobial susceptibility tests for bacteria that grow aerobically. Clinical and Laboratory Standards Institute, Wayne.

Dos Santos, D.C., L.R. Schneider, A.D.S. Barboza, A.D. Campos and R.G. Lund. 2017. Systematic review and technological overview of the antimicrobial activity of Tagetes minuta and future perspectives. Journal of Ethnopharmacology 208: 8-15.

Doughari, J.H. and S. Manzara. 2008. In vitro antibacterial activity of crude leaf extracts of Mangifera indica Linn. African Journal of Microbioloy Research 2: 67-72.

Faizi, S., H. Siddiqi, S. Bano, A. Naz, Lubna, K. Mazhar, S. Nasim, T. Riaz, S. Kamal, A. Ahmad and S.A. Khan. 2008. Antibacterial and antifungal activities of different parts of Tagetes patula. Preparation of patuletin derivatives. Pharmaceutical Biology. 46(5): 309-320.

Faraz, T., G.H. Rizwani, B. Hina and H. Sharif. 2020. Pharmacognostic, antimicrobial and toxicological studies of a seasonal medicinal plant; Tagetes Patula L. RADS Journal of Pharmacy and Pharmaceutical Science 8(4): 1-7.

Feng G., S. Huang, Y. Liu, F. Xiao, J. Liu, Z. Zhang, Q. Chen, Y. Mao, X. Cao, Y. Wang, D. Chen, Y. Zhou, F. Yu, G. Liu, Y. Liu and X. Niu, 2018. The transcriptome analyses of Tagetes erecta provides novel insights into secondary metabolite biosynthesis during flower development. Gene. 660: 18-27.

Gakuubi, M.M., J.M. Wagacha, S.F. Dossaji and W. Wanzala. 2016. Chemical composition and antibacterial activity of essential oils of Tagetes minuta (Asteraceae) against selected plant pathogenic bacteria. International Journal of Microbiology. 2016:1-9.

Hamza, O.J.M., C.J.P., Van Den Bout-van den Beukel, M.I.N Matee, M.J. Moshi, F.H.M. Mikx, H.O. Selemani, Z.H. Mbwambo, A.J.A.M. Van der Ven and P.E. Verweij. 2006. Antifungal activity of some Tanzanian plants used traditionally for the treatment of fungal infections. Journal of Ethnopharmacology 108(1): 124-132.

Hussain A.I., S.A.S. Chatha, S. Noor, M.U. Arshad, Z.A. Khan, H.A. Rathore and M.Z.A. Sattar. 2011. Effect of extraction techniques and solvent systems on the extraction of antioxidant components from peanut (Arachis hypogaea L.) hulls. Food Analytical Methods. 5: 890-896.

Ibrahim S.R.M., H.M. Abdallah, A. M. El-Halawany, A. Esmat and G.A. Mohamed. 2018. Thiotagetin B and tagetannins A and $\mathrm{B}$, new acetylenic thiophene and digalloyl glucose derivatives from Tagetes minuta and evaluation of their in vitro antioxidative and anti-inflammatory activity. Fitoterapia. 125: 78-88.

Jain, R., N. Katare, V. Kumar, A.K. Samanta, S. Goswami and C.K. Shrotri. 2012. In vitro antibacterial potential of different extracts of Tagetes erecta and Tagetes patula. Journal of National Sciences Research 2: 84-90.

Mares, D., B. Tosi, C. Romagnoli and F. Poli. 2002. Antifungal activity of Tagetes patula extracts. Pharmaceutical Biology. 40: 400-404.

Obongoyai B.O., S.O. Wagai and G. Odhiambo. 2010. Phytotoxic effect of selected crude plant extracts on soilborne fungi of common bean. African Crop Science Journal 18(1): $15-22$.

Padalia, H. and S. Chanda. 2015. Antimicrobial efficacy of different solvent extracts of Tagetes erecta $L$. flower, alone and in combination with antibiotics. Applied Microbiology Open Access. 1:1.

Politi F.A.S., G.M. Queiroz-Fernandes, E.R. Rodrigues, J.A. Freitas and R.C.L.R. Pietro. 2016. Antifungal, antiradical and cytotoxic activities of extractives obtained from Tagetes patula L. (Asteraceae), a potential acaricide plant species. Microbial Pathogenesis. 95: 15-20.

Rauha, J.P., S. Remes, M. Heinonen, A. Hopia, M. Kähkönen, T. Kujala, K. Pihlaja, H. Vuorela and P. Vuorela, 2000. Antimicrobial effects of Finnish plant extracts containing flavonoids and other phenolic compounds. International Journal of Food Microbiology. 56(1): 3-12.

Romero, J., P. Liras and J.F. Martin. 1984. Dissociation of cephamycin and clavulanic acid biosynthesis in Streptomyces clavuligerus. Applied Microbiology and Biotechnology. 20: 318-325.

Santos, D.C., L.R. Schneider, A.S. Barboza, AD. Campos and R. Guerra. 2017. Lund Systematic review and technological overview of the antimicrobial activity of Tagetes minuta and future perspectives. Journal of Ethnopharmacology. 208: 815.

Verma, P. and A. Verma. 2012. Evaluation of antibacterial activity of different parts of Tagetes erecta. International Journal of Pharmacy and Life Sciences 3(6): 1766-1768. 